\title{
Paediatric cataract implant surgery outcome
}

Istiantoro

\begin{abstract}
Abstrak
Penelitian ini bertujuan mengevaluasi hasil dari beberapa teknik bedah katarak dan implantasi lensa intraokuler (LIO) pada anak, di Jakarta Eye Center, Jakarta, Indonesia. Penelitian ini merupakan studi retrospektif pada 44 penderita anak (57 mata) yang menjalani bedah katarak dan pemasangan LIO. Tiga macam teknik yang dipakai adalah: 1. Ekstraksi katarak ekstrakapsular dan pemasangan LIO dengan kapsul posterior tetap intak, yang dilakukan pada 21 mata (kelompok 1). 2. Ekstraksi katarak ekstrakapsular dan pemasangan LIO dengan kapsuloreksis posterior (PCCC) dan optic capture, yang dilakukan pada 24 mata (kelompok 2). 3. Ekstraksi katarak ekstrakapsular dan pemasangan LIO dengan kapsuloreksis posterior dan vitrektomi anterior serta optic capture, yang dilakukan pada 24 mata (kelompok 3). Seluruh penderita menjalani evaluasi tindak lanjut selama lebih dari 1 tahun. Hasil penelitian menunjukkan bahwa kekeruhan kapsul posterior (PCO) terjadi pada 20 mata pada kelompok 1. Semua mata mempunyai aksis visual yang jernih pada kelompok 2, dan terjadi PCO hanya pada I mata pada kelompok 3. Kesimpulan : PCCC dengan atau tanpa vitrektomi anterior dan optic capture adalah metoda yang efektif untuk mencegah timbulnya PCO pada bayi atau anak-anak. (Med J Indones 2003; 12: 21-6)
\end{abstract}

\begin{abstract}
This study evaluated the surgical outcome of various surgical technique in paediatric cataract implant surgery, at Jakarta Eye Center, Jakarta, Indonesia. This was a retrospective study of 57 eyes in 44 children who had primary cataract implants surgery. Three surgical techniques used were : 1. Extracapsular cataract extraction with intraocular lens implantation with intact posterior capsule which was performed on 21 eyes (group 1). 2. Extracapsular cataract extraction with intraocular lens implantation and posterior capsulorhexis (PCCC) and optic capture which was performed on 24 eyes (group 2). 3. Extracapsular cataract extraction with intraocular lens implantation, posterior capsulorhexis and anterior vitrectomy which was performed on 24 eyes (group 3). All patients were followed up more than one year. Our results showed that posterior capsule opacity (PCO) was developed in 20 eyes with intact capsules in group I. All eyes had a clear visual axis in group 2. PCO developed only in one eye in group 3. In conclusion, PCCC and optic capture with or without anterior vitrectomy are effective methods in preventing PCO in infant and children. (Med J Indones 2003; 12: 21-6)
\end{abstract}

Keywords: posterior capsule opacification, posterior capsulorhexis, optic capture, anterior vitrectomy

The total amount of blindness in children (best corrected visual acuity less than $3 / 60$ ) is 1.5 million in the world, and it is estimated that there will be 500 thousands new blindness. ${ }^{1}$ The incidence of blindness in children is $15 / 10,000$ in developing countries, and the underlying cause of blindness are malnutrition, and infections which cause a high mortality rate. Furthermore there is lack of support of health services in blind children.

The visual outcome of cataract implant surgery is excellent in adults, but in the past, implanting intraocular lens (IOL) in children has more problems

Department of Opthalmology, Faculty of Medicine, University of Indonesia, Jakarta, Indonesia with its complications. ${ }^{2,3}$ However, the development of viscoelastic agents, IOL, and the techniques of implant in cataract surgery in children have changed and showed dramatic results. ${ }^{4-6}$ The high incidence of posterior capsule opacification (PCO) and fibrosis led to the concept of primary posterior capsulorhexis (PCCC) and optic capture, followed by insertion of optic IOL, with or without anterior vitrectomy at the time of cataract surgery to prevent PCO. Therefore, there are three developments of cataract implant surgery in children: 1. Extracapsular capsular cataract extraction and IOL implantation (ECCE IOL) with intact capsule. 2. ECCE IOL, PCCC and posterior optic capture. 3. ECCE IOL, PCCC and posterior optic capture, and anterior vitrectomy.

The purpose of this study is to evaluate the results of cataract implant surgery in children with the 3 different techniques. 


\section{METHODS}

This is a retrospective study of 57 eyes in 44 children who got primary cataract implants at Jakarta Eye Center from 1993 to 1999. Fifty-five were congenital, and two eyes were traumatic cataract. Total lens opacity was found in 25 eyes, and the rest showed partial opacity. The mean age at time of surgery was 5.7 years, that ranged from 4 months to 14 years. The distribution of age group and the 3 surgical techniques can be seen in Table 1 .

\section{Surgical technique}

All operations were performed by a single surgeon. General anaesthesia was used in all cases. The scleral or corneal tunnel incision was made with 2.5 or 3.0 $\mathrm{mm}$ keratome. The aqueous humor was exchanged with high viscosity sodium hyaluronate through the tunnel incision. The anterior capsule was opened with a technique called continuous curve linear capsulotomy (CCC) using a bend 23 needle. Multilamellar hydrodissection were performed. Lens material was removed using phaco hand piece or irrigation aspiration hand piece of phaco machine with aspiration mode. The posterior capsule management and IOL insertion were managed in 3 different techniques.

1. After nuclear material removal, the posterior capsule was leaved intact, and the ovoid polymethyl methacrylate (PMMA) IOL was inserted in the bag. Vitrectomy was performed if there was posterior capsule rupture with vitreous lost, and the IOL inserted to the ciliary sulcus. Twenty-one eyes were performed in this fashioned.

2. After nuclear material removal, the visco-elastic materials were injected into the anterior chamber, then posterior capsule was opened at the central area to make a triangular flap using a 27-bend needle. The posterior capsular flap was grasped with Utrata forceps, and a 4.5 to $5.5 \mathrm{~mm}$ diameter continuous curve linear capsulectomy (PCCC) was performed. Additional viscoelastic materials are injected as necessary through the posterior capsular tear to push the vitreous face away as tear enlarging. The injection of the viscoelastic materials should be very carefully done; it should not push the capsular tear, as it may cause difficulties in grasping the triangular tear. Too much viscoelastic material may extend the tear to the equator (tear escape). The ovoid PMMA IOL or $5.5 \mathrm{~mm}$ optic acrylic IOL was inserted in the bag, and then was pushed through PCCC opening with a Sinskey hook (posterior optic capture). If the integrity of posterior capsule is lost (peripheral tear), it is impossible to do the posterior optic capture. In this study twelve eyes were performed in this technique.

3. After nuclear material removal and PCCC was completed, an anterior vitrectomy was performed through the incision and the irrigation cannula by paracenthesis. The ovoid PMMA IOL or $5.5 \mathrm{~mm}$ optic acrylic IOL was inserted in the bag and then pushed through PCCC opening with a Sinskey hook (optic capture). Twenty-four eyes were performed in this technique (Table 1).

Table 1. The surgical techniques in age groups (year)

\begin{tabular}{|c|c|c|c|c|c|}
\hline \multirow{2}{*}{$\begin{array}{l}\text { Surgical } \\
\text { technique }\end{array}$} & \multicolumn{4}{|c|}{ Age (year) } & \multirow{2}{*}{ Total } \\
\hline & Less 3 & $3-6$ & $6-12$ & More 12 & \\
\hline $\begin{array}{l}\text { Group } 1 \\
\text { ECCE+IOL }\end{array}$ & 3 & 11 & 5 & 2 & 21 \\
\hline $\begin{array}{l}\text { Group } 2 \\
\text { ECCE+IOL+ } \\
\text { Optic Capture }\end{array}$ & - & 5 & 5 & 2 & 12 \\
\hline $\begin{array}{l}\text { Group } 3 \\
\text { ECCE+IOL+ } \\
\text { Vit ant+ } \\
\text { Optic capture }\end{array}$ & 15 & 7 & 2 & - & 24 \\
\hline Total & 18 & 25 & 12 & 4 & 57 \\
\hline
\end{tabular}

ECCE $=$ Extracapsular cataract extraction, $\mathrm{IOL}=$ intra ocular lens, vit ant $=$ anterior vitrectomy

In all cases the residual visco-elastic substance was removed using automatic irrigation aspiration. During visco-elastic removal the IOL was hold with the Sinskey hook to prevent optic out of the posterior optic capture because the positive vitreous pressure. The wound was closed with interrupted 10-0 nylon sutures and $0.01 \%$ carbachol and balance salt solution (BSS ${ }^{\mathrm{R}}$ ) was injected into the anterior chamber. The anterior chamber was checked if there was vitreous strand and vitrectomy was performed if necessary. At the end of surgery the eye was dressed with subconjunctival injection of dexamethasone and antibiotic, an eye patch and shield. Dexamethasone and antibiotic eye drops was given four times a dąy.

Postoperative examination performed at day 1 , weeks 1,2 and 4, then every 3 months. Refraction, slit 
lamp, and indirect ophthalmoscope were performed upon every visit. Special attention was paid to the formation of posterior capsule opacification (PCO) or fibrosis. Second procedure was performed, either Nd YAG Laser capsulotomy or capsulectomy with anterior vitrectomy if necessary, when evidence of $\mathrm{PCO}$ or fibrosis reduce best corrected visual acuity.

\section{RESULTS}

The surgical complications: in-group 1 (ECCE + IOL), integrity lost of CCC was found in 8 eyes, and posterior capsule rupture and vitreous lost in 1 eye. Posterior capsule opacity was found in 20 eyes, except one eye that had complication during procedure i.e. posterior capsule rupture and vitreous lost. The secondary treatment of Nd-Yag Laser was performed in 13 eyes, and posterior capsulectomy and anterior vitrectomy were performed in 5 eyes.

\section{In-group 2 (ECCE+IOL+PCCC+OPTIC CAPTURE),} integrity lost of PCCC were found in 2 eyes, and anterior $\mathrm{CCC}$ in 6 eyes. Intraocular lens were implanted at ciliary sulcus of 2 eyes without optic capture. Posterior capsule opacity was not found in this group.

In-group 3 (ECCE+PCCC+Anterior Vitrectomy + IOL Optic Capture), fibrosis was found in 1 eye of a
4 months old child. The secondary treatment (capsulectomy and anterior vitrectomy) was performed. The surgical complications: integrity lost of CCC was found in 4 eye, and PCCC in 4 eyes. The IOL insertion at ciliary sulcus was done in 8 eyes, and without optic capture in 4 eyes (Table 2).

Post operative visual acuity ranged from 0.1 to 0.7 . The visual outcomes of the patients in age group less than 3 years were difficult to measure. However, in 15 eyes $(85 \%)$ from group $2 \& 3$, visual axis remained clear at last visit. In age group 3-6 years, best-corrected visual acuity (BCVA) 0.1 was achieved in 2 eyes, BCVA between 0.2 to 0.4 in 9 eyes, and BCVA more than 0.5 in 9 eyes. In age group more than 12 years, BCVA 0.2 to 0.4 was achieved in 2 eyes, and BCVA more than 0.5 in 2 eyes. In group 1 , posterior capsule opacity had significantly reduced the visual outcome. Therefore, secondary treatments of Nd-Yag Laser were done in 12 eyes, and capsulectomy with anterior vitrectomy in 5 eyes. One eye had clear visual axis in which anterior vitrectomy had to be done as primary treatment because posterior rupture with vitreous lost occurred (table 3 ). In this series we found 3 patients who developed myopic shift during follow up.

Table 2. Surgical complications, posterior capsule opacity and secondary treatment

\begin{tabular}{|c|c|c|c|c|c|c|c|c|}
\hline & \multicolumn{3}{|c|}{ Integrity Lost } & \multicolumn{2}{|c|}{ IOL fixation } & \multirow[t]{2}{*}{$\mathrm{PCO}$} & \multicolumn{2}{|c|}{ Second treatment } \\
\hline & $\mathrm{CCC}$ & VL & $\mathrm{PCCC}$ & $\mathrm{CS}$ & Bag & & Nd-Yag & Cap+Vit \\
\hline $\begin{array}{l}\text { Group 1 } \\
(\mathrm{N}=21)\end{array}$ & 8 & 1 & - & 9 & 12 & 12 & 5 & \\
\hline $\begin{array}{l}\text { Group } 2 \\
(\mathrm{~N}=12)\end{array}$ & 6 & & 2 & 6 & 6 & - & & \\
\hline $\begin{array}{l}\text { Group } 3 \\
(\mathrm{~N}=24)\end{array}$ & 4 & & 4 & 8 & 14 & 1 & 1 & \\
\hline
\end{tabular}

$\mathrm{CCC}=$ anterior capsulorhexis, $\mathrm{VL}=$ vitreous lost, $\mathrm{PCCC}=$ posterior capsulorhexis, $\mathrm{CS}=$ cilliary sulcus, $\mathrm{PCO}=$ posterior capsule opacification, $\mathrm{Cap}+\mathrm{Vit}=$ capsulectomy + anterior vitrectomy 
Table 3. Correlation of surgical technique, PCO and visual outcome

\begin{tabular}{|c|c|c|c|c|c|c|}
\hline \multirow{2}{*}{ Surgical technique } & \multirow{2}{*}{$\operatorname{PCO}(n)$} & \multicolumn{3}{|c|}{ BCVA } & \multicolumn{2}{|c|}{ Sec. treatment } \\
\hline & & $\leq 0.1$ & $0.2-0.4$ & $>0.5$ & Nd-Yag & Ant. Vit \\
\hline $\begin{array}{l}\text { Group 1 } \\
(\mathrm{n}=18)\end{array}$ & 17 & & 5 & 11 & 12 & 5 \\
\hline $\begin{array}{l}\text { Group } 2 \\
(n=12)\end{array}$ & 0 & 2 & 6 & 4 & 0 & 0 \\
\hline $\begin{array}{l}\text { Group } 3 \\
(n=24)\end{array}$ & 1 & & & 4 & 2 & \\
\hline
\end{tabular}

$\mathrm{PCO}=$ posterior capsule opacity, $\mathrm{BCVA}=$ best corrected visual acuity, $\mathrm{Ant}-\mathrm{Vit}=$ anterior vitrectomy, sec. treatment $=$ secondary treatment

\section{DISCUSSION}

Cataract in children is still difficult to manage. It remains the cause of significant partial blindness. Cataract in children is different from adults. A child's eye is not a miniature from an adult's eye, and time of surgery and aphakic correction always have effects on visual development. Implanting an intraocular lens into an adult eye as an aphakic correction is usually extremely successful. At present, both surgical technique to remove cataract and the IOL design have improved. Phacoemulsification has become the state of art and widely used in many countries. The materials and design of IOL with high degree of biocompatibility, soft flexibility allows smaller incision and less invasive surgery. However, such improvements are not enough to be applicable for cataract in children. Cataract surgery in children has more problems. Implanting IOL in newborn eye has many difficulties as follows: preoperative, intraoperative and postoperative care. Preoperative difficulties: risk of general anaesthesia, associated conditions, late diagnosis and IOL power calculation. Intraoperative difficulties: small eye, low scleral and corneal rigidity, solid vitreous tends to yield positive vitreous pressure, thin elastic lens capsule causes difficulty in capsulorhexis. Postoperative difficulties: exaggerated uveal response to inflammation, formation of secondary posterior opacification or fibrosis, secondary glaucoma, change in axial length with myopic shift and challenge in amblyopic treatment.

Implanting IOL into a child's eye for aphakic correction was pioneered by Binkhorst and Gobin, and Hiles. ${ }^{8}$ High incidence of posterior capsule opacity (PCO) or fibrosis was reported following IOL implantation in the capsular bag with intact posterior capsule. ${ }^{9-11}$ Post operative exaggerated uveal responses/inflammations caused anterior and posterior capsule opacity or fibrosis, posterior synechiae, IOL optic capture, capsule contracture and IOL decentration. In this study 17 eyes (group 1) with intact posterior capsule developed PCO. Twelve eyes required $\mathrm{Nd}-\mathrm{Yag}$ laser capsulotomies and five eyes required capsulectomies and anterior vitrectomies. All capsulectomy and anterior vitrectomy were performed in patients under 6 years old with thick posterior capsule fibrosis. In this group 1, only one eye have a clear visual axis as a result of primary anterior vitrectomy due to posterior rupture and vitreous lost during surgery (Table 3 ).

Several studies reported to prevent PCO formation by opening the posterior capsule as a primary procedure. Gimbel ${ }^{5}$ opened the posterior capsule by continuous curve linear capsulectomy (PCCC) and optic capture. Posterior optic capture is a challenging procedure. Performing PCCC is difficult. It needs surgeon skill and experience to anticipate the diameter of PCCC to ensure permanent optic capture. The diameter of PCCC should be $1 \mathrm{~mm}$ smaller than optic diameter of the IOL. Zetterstrom ${ }^{12}$ reported clear visual axis by implanting heparin-surfacemodified IOLs after performing CCC of the anterior and posterior capsules. Several studies ${ }^{9,13-15}$ also reported prevention of $\mathrm{PCO}$ by performing both PCCC and anterior vitrectomy, removing the vitreous scaffold for lens epithelial migration. The capsular fusion on the anterior of the optic IOL might 
diminish central lens epithelial migration or cell movement over the lens optic, which is not a suitable substrate for lens cell survival. ${ }^{15}$ Beside to prevent secondary PCO, optic capture enhances IOL and centration. Consequently, decentered PCCC could cause IOL decentration. Vasavada ${ }^{6}$ reported that anterior vitrectomy along with $\mathrm{PCCC}$ is desirable as a primary procedure in children younger than 5 years. Our experience showed that PCCC with optic capture and anterior vitrectomy in younger children could prevent PCO / fibrosis. Only one eye of the 4 months old infant developed posterior fibrosis over the anterior of the vitreous body (Table 2, 3). It may be caused by the procedure that only cut the viscoelastic substance during anterior vitrectomy. During the second surgical procedure the optic of IOL was not captured because the diameter of PCCC was too small. Surgeon should keep in mind that the anterior vitrectomy should be performed intensively in the entire anterior surface of vitreous body, together with as large as possible PCCC.

The visual outcome of paediatric cataract surgery created challenging problems. A child with dense congenital cataract has to fight both amblyopia and spectacles correction to adjust eye growth. Post operative care includes repeated spectacle corrections and intensive care to promote visual development. These need a team work of paediatrician, ophthalmologist, optometrist etc. Intensive postoperative care is necessary to achieve good visual acuity in the future. Intra occular lens power calculation should anticipate the ocular growth. The eye of an adult is $40-50 \%$ larger than that of an the infant. The axial length of a newborn child's eye is $17 \mathrm{~mm}$, while in adult's eye it is 23.5 -mm. ${ }^{17}$ Most ocular growth occurs during the first 2 years, particularly in the first year. Myopic shift due to axial growth during childhood has led some investigators to implant undercorrected IOL. ${ }^{12,16}$ In this study, best corrected visual acuity (BCVA) $\geq 0.5$ was achieved in 21 eyes $(36.8 \%)$; BCVA $\geq 0.2 \leq 0.4$ in 11 eyes $(19.3 \%)$ and $\mathrm{BCVA} \leq 0.1$ in 2 eyes $(3.5 \%)$. In the rest 10 infant eyes $(17.5 \%)$, the visual acuity was not able to be measured, the same with the other 14 eyes $(22.4 \%)$ that were amblyopia. However, these eyes had clear visual axis (surgical group 2 \& 3 ) and only one eye (group 3) need anterior vitrectomy as secondary treatment. Intensive postoperative care from paediatric medical team was needed to develop visual acuity together with the cooperation and support from their parents.
In conclusion, PCCC with optic capture could prevent PCO. Vitrectomy anterior along with PCCC and optic capture is more desirable in younger children, and anterior vitrectomy should be performed intensively (entire anterior) with as large as possible PCCC. Cataract implant surgery should be done by a skilled experienced surgeon to ensure good visual outcome in the future.

\section{REFERENCES}

1. World Heath Organization. Prevention of Childhood Blindness. Geneva: WHO; 1992.

2. Menezo JL, Taboada JF, Ferrer E. Complications of intraocular lenses in Children. Trans Ophthalmol Soc UK 1985; 104: 546-52.

3. Hiles DA, Watson BA. Complications of implant surgery in children. Am Intra-Ocular Implant Soc J 1979; 5: 2432.

4. Zetterstrom C, Kugelberg U, Lundgren B, SyrenNordqvist S. After cataract formation in newborn rabbits implanted with intraocularlenses. J Cataract Refract Surg 1996; 22: 85-8.

5. Gimbel HV. Posterior continuous curvelinear capsulorhexis and optic capture of intraocular lens to prevent secondary opacification in pediatric cataract surgery. J Cataract Refract Surg 1997; 23: 652-5.

6. Vasavada A, Desai J. Primary posterior capsulorhexis with and without anterior vitrectomy in congenital cataracts. . J Cataract Refract Surg 1997; 23: 645-51.

7. Binkhorst $\mathrm{CD}$, Gobin $\mathrm{MH}$. Treatment of congenital and juvenile cataract with intraocular lens (pseudophakoi) $\mathrm{Br}$ J Ophthalmol 1970; 54:759-65.

8. Hiles DA. Intraocular lens implantation in children with monocular cataract; 1974-1983. Ophthalmology 1984; 91: 1231-7.

9. Buckley EG, Klombers LA, Seaber JH, Scalise-Gordy A, Minster R. Management of of posterior capsule during pediatric intraocular lens implantation. Am J Ophthalmol 1993; 115: 722-8.

10. Hiles DA, Hered RW. Modern lens implants in children with new age limitation. J Cataract Refract Surg 1987; 13: 493-7.

11. Oliver M, Milstein A, Pollack A. Posterior chamber lens implantation in infants and juveniles. Eur J Implant Refract Surg 1990; 2: 309-14.

12. Zetterstrom C, Kugelberg U, Oscarson C. Cataract surgery in children with capsulorhexis of anterior and posteriūi capsules and heparin-surface-modified intraocular lenses. J Cataract Refract Surg 1994; 20:599-601.

13. Mackool RJ, Chhatiawala H. Pediatric cataract surgery and intraocular lens implantation: a new technique for preventing or existing postoperative secondary membranes. J Cataract Refract Surg 1991; 17:62-6.

14. Keech RV, Tongue AC, Scott WE. Complications after surgery for congenital and infantile cataract. Am J Ophthalmol 1989; 108:136-41. 
15. Koch DD, Kohnen T. Retrospective comparison of techniques to prevent secondary cataract formation after posterior chamber intraocular lens implantation in infants and children. J Cataract Refract Surg 1997; 23:567-3.
16. Dahan E, Welsh NH, Salmelson BD. Posterior chamber implant in unilateral congenital and developmental cataracts. Eur J implant Refract Surg 1990; 2:295-302.

17. Gordon RA, Donzis PB. Refractive development of the human eye. Ach of Ophthalmool 1985; 103:785-9. 